\title{
PENGARUH KEDISIPLINAN PIMPINAN TERHADAP KINERJA PEGAWAI DI KANTOR KELURAHAN LOMPO RIAJA KABUPATEN BARRU
}

\author{
Dwi Nur Handayani \\ STIA Bina Taruna Gorontalo \\ dwinurhndayani2@gmail.com
}

\begin{abstract}
ABSTRAK
Penelitian ini bertujuan untuk mengetahui pengaruh kedisplinan pimpinan terhadap kinerja pegawai di Kantor Kelurahan Lompo Riaja Kabupaten Barru. Metode penelitian yang digunakan adalah jenis penelitian deskriptif kuantitatif dengan menjelaskan hubungan dan anggota sampelnya sebanyak 16 orang pegawai dengan menggunakan metode sampling jenuh. Jenis deskriptif kuantitatif dengan tipe penelitian survei yakni penelitian lapangan untuk mengumpulkan data informasi dari responden melalui kuesioner sebagai pengumpulan data secara langsung di lokasi penelitian. Variabel penelitian terdiri dari variabel independen (x) yaitu kedisiplinan pimpinan, sedangkan variabel dependen (y) yaitu kinerja pegawai. Tekni analisis data untuk mengetahui kedisiplinan pimpinan dan kinerja pegawai digunakan teknik analisis frekuensi dan untuk mengetahui pengaruh antara kedisiplinan pimpinan terhadap kinerja pegawai maka digunakan teknik analisis regresi linear sederhana dengan bantuan SPSS 16.

Hasil penelitian menunjukkan adanya pengaruh yang cukup kuat kedisiplinan pimpinan terhadap kinerja pegawai di Kantor Kelurahan Lompo Riaja Kabupaten Barru, dimana kedisiplinan pimpinan pada kantor Kelurahan Lompo Riaja Kabupaten Barru masih berada pada kategori kurang disiplin, hal ini bisa dilihat dari nilai akumulasi kedisiplinan pimpinan dengan persentase sebesar 56,25 persen; kinerja pegawai di kantor Kelurahan Lompo Riaja Kabupaten Barru masih berada pada kategori kurang baik, hal ini bisa dilihat dari nilai akumulasi kinerja pegawai dengan persentase sebesar 37,5 persen; Hasil uji regresi yang telah dilakukan secara parsial menunjukkan bahwa pengaruh kedisiplinan pimpinan sebagai variabel independen terhadap kinerja pegawai sebagai variabel dependen memiliki pengaruh yang lemah dan ada beberapa koefisien korelasi yang bernilai negatif, artinya tidak memiliki kontribusi terhadap kinerja pegawai; Hasil uji regresi yang telah dilakukan secara simultan menunjukkan bahwa kedisiplinan pimpinan berpengaruh terhadap kinerja pegawai, ini dapat dilihat pada nilai pearson correlation sebesar 0,641 artinya pengaruh kedisiplinan pimpinan terhadap kinerja pegawai cukup kuat.
\end{abstract}

Kata Kunci: Kedisiplinan, Pimpinan, Kinerja, Pegawai

PENDAHULUAN

Mewujudkan Pegawai Negeri Sipil yang handal, profesional, dan bermoral sebagai penyelenggara pemerintahan yang menerapkan prinsip-prinsip pemerintahan yang baik (good governance), maka 
Pegawai Negeri Sipil sebagai unsur aparatur negara dituntut untuk setia kepada pancasila, Undang-Undang Dasar Negara Republik Indonesia Tahun 1945, Negara Kesatuan Republik Indonesia, dan Pemerintah, bersikap disiplin, jujur, adil, transparan, dan akuntabel dalam melaksanakan tugas.

Disiplin merupakan suatu prasyarat dan kebutuhan bagi suatu organisasi untuk maju dan berkembang sesuai dengan visi, misi dan tujuan yang ingin dicapai suatu organisasi. Adanya disiplin kerja yang diterapkan oleh suatu organisasi tersebut akan memberikan suatu seni dan ilmu bagi suatu organisasi didalam memahami, menyikapi, dan menindaklanjuti aspek-aspek disiplin kerja sebagai suatu pertimbangan organisasi dalam meningkatkan kinerjanya.

Dalam upaya meningkatkan kedisiplinan Pegawai Negeri Sipil tersebut sebenarnya pemerintah Indonesia telah memberikan suatu regulasi dengan dikeluarkannya Peraturan Pemerintah Nomor 53 Tahun 2010 tentang Peraturan Disiplin Pegawai Negeri Sipil. Dalam Peraturan Pemerintah mtersebut yang dimaksud dengan disiplin Pegawai Negeri Sipil adalah kesanggupan pegawai negeri sipil untuk menaati kewajiban dan menghindari larangan yang ditentukan dalam peraturan perundang-undangan dan/atau peraturan kedinasan yang apabila tidak ditaati atau dilanggar dijatuhi hukuman disiplin.

Pegawai Negeri Sipil sebagai aparat pemerintah dan abdi masyarakat diharapkan selalu siap sedia menjalankan tugas yang telah menjadi tanggung jawabnya dengan baik, namun realitanya sering terjadi dalam suatu instansi pemerintah, para pegawainya melakukan pelanggaran yang menimbulkan ketidak efektifan kinerja pegawai yang bersangkutan.

Disiplin merupakan salah satu dari beberapa faktor yang mempengaruhi kinerja pegawai. Karena tanpa adanya disiplin, maka segala kegiatan yang akan dilakukan akan mendatangkan hasil yang kurang memuaskan dan tidak sesuai dengan harapan. Hal ini dapat mengakibatkan kurangnya pencapaian sasaran dan tujuan organisasi baik organisasi pemerintah maupun non pemerintah.

Faktor kedisiplinan memegang peranan yang amat penting dalam pelaksanaan kerja pegawai. Seorang pegawai yang mempunyai tingkat kedisiplinan yang tinggi akan tetap bekerja dengan baik walaupun tanpa diawasi oleh atasan. Seorang pegawai yang disiplin tidak akan mencuri waktu kerja untuk melakukan hal-hal lain yang tidak ada kaitannya dengan pekerjaan. Demikian juga pegawai yang mempunyai kedisiplinan akan mentaati peraturan yang ada dalam lingkungan kerja dengan kesadaran yang tinggi tanpa ada rasa paksaan. Pada akhirnya pegawai yang mempunyai kedisiplinan kerja yang tinggi akan mempunyai kinerja yang baik karena waktu kerja dimanfaatkannya sebaik mungkin untuk melaksanakan pekerjaan sesuai dengan target yang telah ditetapkan.

Pimpinan yang teladan mempunyai peran yang sangat penting dalam menentukan kinerja pegawai, karena seorang pimpinan 
harus memberikan contoh yang baik, mempunyai disiplin yang baik, jujur, serta sesuai dengan perbuatannya. Jika pimpinan yang teladan mempunyai kedisiplinan yang baik maka dengan sendirinya bawahannya akan ikut baik, tetapi jika pimpinan yang kurang baik, maka bawahannya akan kurang baik. Pimpinan yang baik harus menyadari bahwa perilakunya akan dicontoh dan diteladani oleh bawahannya jika mempunyai kedisiplinan yang baik. Dari uraian diatas dapat disimpulkan bahwa sebuah instansi ingin mendapatkan bawahan yang mempunyai kinerja yang baik pula, karena seorang pimpinan akan selalu menjadi panutan yang baik bagi pegawainya.

Keberhasilan

kedisiplinan pimpinan akan menentukan pencapaian kinerja pegawai, khususnya disiplin dalam bersikap terhadap instansi, pekerjaan dan pegawai yang bekerja dalam mengembangkan kinerja organisasi. Tidak mungkin seorang memotivasi orang lain, kalau ia tidak dapat menimbulkan kepercayaan dan respek. Sedangkan hal ini banyak ditentukan oleh cara berpikir, perilaku dan berbuat yang berdisiplin. Mutu kepemimpinan banyak ditentukan oleh disiplin, terutama disiplin pribadi (selfdiscipline) atau pengendalian diri yang dapat ditumbuhkan seorang dalam dirinya.

Teladan pimpinan sangat berperan dalam menentukan kinerja pegawai karena pimpinan dijadikan teladan dan panutan oleh para bawahannya. Pimpinan harus memberi contoh yang baik, berdisiplin yang baik, jujur, dan adil, serta sesuai kata dengan perbuatan. Semakin tinggi kedisiplinan pimpinan maka semakin bagus kinerja pegawainya, begitupun sebaliknya. Pimpinan jangan mengharapkan kinerja bawahannya baik jika dia sendiri kurang disiplin, pimpinan harus menyadari bahwa perilakunya akan dicontoh dan diteladani oleh bawahannya. Hal inilah yang mengharuskan pimpinan mempunyai kedisiplinan yang tinggi agar para bawahannya pun mempunyai kinerja yang baik pula.

Seorang pimpinan harus mampu menciptakan suasana yang kondusif, memberikan cukup perhatian, memberikan penghargaan terhadap prestasi kerja, menjalin komunikasi yang baik dengan seluruh pegawai. Untuk menciptakan kondisi demikian, diperlukan adanya usaha-usaha untuk meningkatkan kualitas dan kinerja bagi setiap pegawai. Ini dimungkinkan bila terwujudnya peningkatan kinerja pegawai secara optimal. Sebab bagaimanapun juga tujuan sebuah instansi, salah satunya adalah untuk meningkatkan kesejahteraan dan kinerja pegawai.

Sebagaimana dikatakan oleh Mangkunegara (2012:9), bahwa kinerja pegawai (prestasi kerja) adalah hasil kerja secara kualitas dan kuantitas yang tercapai oleh seseorang pegawai dalam melaksanakan tugasnya sesuai tanggungjawab yang diberikan kepadanya.

Pimpinan yang terdapat pada organisasi harus memiliki kelebihankelebihan dibandingkan dengan bawahannya, yaitu pegawai yang terdapat di organisasi yang bersangkutan, sehingga dapat 
menunjukkan kepada bawahannya untuk bergerak, bergiat, berdaya upaya yang tinggi untuk mencapai tujuan-tujuan yang telah ditetapkan. Akan tetapi hanya mengarahkan seluruh pegawai saja tidak cukup, sehingga perlu adanya suatu dorongan agar para pegawainya mempunyai minat yang besar terhadap pekerjaannya. Atas dasar inilah selama perhatian pimpinan diarahkan kepada bawahannya, maka kinerja pegawainya akan tinggi.

Peningkatan kinerja pegawai menjadi penting mengingat perubahan arah kebijakan pemerintah sebagaimana dikehendaki oleh semangat reformasi untuk lebih luas memberi ruang gerak dan peran serta yang lebih besar bagi masyarakat dalam kegiatan pemerintahan dan pembangunan, dimana pemerintah beserta aparaturnya lebih berperan sebagai fasilitator. Perubahan arah kebijakan ini membawa implikasi terhadap kemampuan profesionalisme pegawai dalam menjawab tantangan era globalisasi dalam menghadapi persaingan ketat dengan negara-negara lain didunia.

Sebagaimana yang diketahui bahwa kinerja aparat pemerintah bertujuan untuk memberikan pelayanan publik yang mendahulukan kepentingan umum, mempermudah urusan publik, mempersingkat pelayanan dan memberikan kepuasan kepada publik.

Kinerja pelayanan pemerintah masih lemah, pemahaman tentang pemerintahan yang baik tidak mampu dijalankan dengan yang diharapkan oleh masyarakat akibat yang terjadi pengguna jasa tidak merasa puas dengan apa yang diberikan kepada mereka. Perbaikan dalam penyelenggaraan pemerintah harus terus dilakukan, bagaimana menimbulkan dan menguatkan kinerja aparat sebagai abdi negara dan abdi masyarakat yang mau tidak mau harus berupaya meningkatkan kemampuan kerjanya semaksimal mungkin, karena pelaksanaan tugas pelayanan oleh pemerintah kelurahan sangat tergantung pada kinerja aparaturnya. Sedangkan masyarakat harus dapat menilai kinerja kantor pemerintah dari kualitas pelayanan yang diterimanya.

Berdasarkan pengamatan awal penulis pada Kantor Kelurahan Lompo Riaja Kabupaten Barru, masih rendahnya kedisiplinan pimpinan dan kinerja pegawai pada kantor tersebut terlihat dari pimpinan dan pegawai yang masuk jam 09.00 WITA dari ketentuan masuk kerja jam 07.30 WITA sehingga terkadang masyarakat sudah berada di kantor tersebut untuk memperoleh pelayanan harus menunggu, pegawai meninggalkan kantor pada saat jam kerja tanpa izin pimpinan, kemampuan pegawai yang rendahpun dapat dilihat dari keterampilan mengoprasionalkan komputer. Kedisiplinan pimpinan yang lemah dalam mengawasi atau mengontrol pelaksanaan tugas yang dikerjakan oleh para pegawainya menyebabkan kinerja dari para pegawai kelurahan sulit ditingkatkan.

\section{PERMASALAHAN}

Berdasarkan uraian dari latar belakang, maka rumusan permasalahaan dalam penelitian ini adalah (1) Bagaimana kedisiplinan pimpinan di Kantor Kelurahan 
Lompo Riaja Kabupaten Barru? Bagaimana kinerja pegawai di kantor Kelurahan Lompo Riaja Kabupaten Barru? (2) Bagaimana pengaruh kedisiplinan pimpinan terhadap kinerja pegawai di Kantor Kelurahan Lompo Riaja Kabupaten Barru?

\section{TUJUAN DAN MANFAAT PENELITIAN}

\section{Tujuan Penelitian}

Adapun tujuan penelitian adalah untuk mengetahui: Kedisiplinan pimpinan di Kantor Kelurahan Lompo Riaja Kabupaten Barru; Kinerja pegawai di Kantor Kelurahan Lompo Riaja Kabupaten Barru; dan Pengaruh kedisiplinan pimpinan terhadap kinerja pegawai di Kantor Kelurahan Lompo Riaja Kabupaten Barru.

\section{Manfaat Penelitian}

Adapun manfaat secara teoritis bahwa hasil penelitian ini dapat dijadikan sebagai acuan atau rujukan bagi dunia perguruan tinggi khususnya jurusan Ilmu Administrasi Negara dalam mengembangkan teoritis yang lebih luas dan sebagai refrensi bagi peneliti lain yang meneliti masalah sejenis.

Secara praktis penelitian ini diharapkan dapat dijadikan masukan bagi Kantor Kelurahan Lompo Riaja Kabupaten Barru, tentang arti pentingnya pengaruh kedisiplinan pimpinan terhadap keberhasilan pekerjaan dan terciptanya kinerja pegawai yang akan memberikan dampak positif bagi instansi tersebut dan untuk pelaksanaan tugas-tugas yang akan datang.

\section{METODE PENELITIAN}

Metode penelitian yang digunakan dalam penelitian ini adalah jenis penelitian adalah deskriptif kuantitatif dengan menjelaskan hubungan dan anggota sampelnya sebanyak 16 orang pegawai dengan menggunakan metode sampling jenuh. Jenis deskriptif kuantitatif dengan tipe penelitian survey yakni penelitian lapangan untuk mengumpulkan data informasi dari responden melalui kuesioner sebagai pengumpulan data secara langsung di lokasi penelitian. Variabel penelitian terdiri dari variabel independen (x) yaitu kedisiplinan pimpinan, sedangkan variabel dependen (y) yaitu kinerja pegawai. Tekni analisis data untuk mengetahui kedisiplinan pimpinan dan kinerja pegawai digunakan teknik analisis frekuensi dan untuk mengetahui pengaruh antara kedisiplinan pimpinan terhadap kinerja pegawai maka digunakan teknik analisis regresi linear sederhana dengan bantuan SPSS 16.

\section{POPULASI DAN SAMPEL}

\section{Populasi}

Menurut Sugiyono (2012:119) yang menyatakan bahwa populasi adalah wilayah generalisasi yang terdiri atas obyek/subyek yang mempunyai kualitas dan karakteristik tertentu ditetapkan oleh peneliti untuk dipelajari dan kemudian ditarik kesimpulannya. Pada penelitian ini populasinya adalah seluruh pegawai di Kantor Kelurahan Lompo Riaja Kabupaten Barru dengan jumlah pegawai 16 orang. 


\section{Sampel}

Metode penarikan sampel yang digunakan adalah metode sampling jenuh, dimana jumlah populasi yang ada dapat dijadikan sebagai jumlah keseluruhan sampel sebagaimana yang dikutip dari buku Sugiyono (2012:126), sehingga jumlah ditentukan sebanyak 16 orang.

\section{Operasional Variabel Penelitian}

Dalam penelitian ini yang merupakan variabel independen (x) yaitu kedisiplinan pimpinan, sedangkan variabel dependen (y) yaitu kinerja pegawai. Untuk memudahkan dalam pengujian hipotesis, maka peneliti menetapkan variabel penelitian sebagai berikut:

a. Variabel bebas atau Independent Variable (X)

Menurut Rivai \& Mulyadi (2012:34-35) ada beberapa indikator kepemimpinan (variabel $\mathrm{X}$ ) sebagai berikut:
a. Fungsi instruksi
b. Fungsi konsultasi
c. Fungsi partisipasi
d. Fungsi delegasi
e. Fungsi pengendalian

b. Variabel terikat atau Dependent Variable (Y)

Menurut Arep \& Tanjung (2003:204), ada beberapa indikator motivasi kerja (variabel Y) sebagai berikut:
a. Bekerja sesuai standar
b. Senang dalam bekerja
c. Merasa berharga
d. Bekerja keras
e. Sedikit pengawasan

\section{TEKNIK ANALISIS DATA}

1. Untuk mengetahui kedisiplinan pimpinan dan kinerja pegawai maka, digunakan teknik analisis frekuensi dengan rumus:

$$
\mathrm{P}=\frac{\mathrm{f}}{\mathrm{N}} \times 100 \%
$$

Keterangan:

$\mathrm{P}=$ Persentase

$\mathrm{f}=$ frekuensi

$\mathrm{N}=$ Jumlah sampel

$100 \%=$ Bilangan tetap

2. Untuk mengetahui pengaruh antara kedisiplinan pimpinan terhadap kinerja pegawai maka digunakan teknik analisis regresi linear sederhana dengan bantuan SPSS 16, yaitu:

$$
Y=a+b X
$$

Harga a dapat diketahui dengan menggunakan rumus sebagai berikut:

$$
a=\frac{\sum y \sum x^{2}-\sum x \sum x y}{n \sum x^{2}-\left(\sum x\right)^{2}}
$$

Harga b dapat diketahui dengan menggunakan rumus sebagai berikut

Keterangan:

$$
b=\frac{n \sum x y-\sum x \sum y}{n \sum x^{2}-\left(\sum x\right)^{2}}
$$

$\mathrm{Y}=$ Nilai yang diprediksikan

$\mathrm{a}=$ konstanta atau bila harga $\mathrm{X}=0$

$\mathrm{b}=$ koefisien regresi

$\mathrm{X}=$ Nilai variabel independen

$\mathrm{n}=$ Banyaknya sampel 


\section{HASIL PENELITIAN DAN PEMBAHASAN}

\section{A. Kedisiplinan Pimpinan (X)}

Pimpinan yang teladan mempunyai peran yang sangat penting dalam menentukan kinerja pegawai, karena seorang pimpinan harus memberikan contoh yang baik, mempunyai disiplin yang baik, jujur, serta sesuai dengan perbuatannya. Jika pimpinan yang teladan mempunyai kedisiplinan yang baik maka dengan sendirinya bawahannya akan ikut baik, tetapi jika pimpinan yang kurang baik, maka bawahannya akan kurang baik. Pimpinan yang baik harus menyadari bahwa perilakunya akan dicontoh dan diteladani oleh bawahannya jika mempunyai kedisiplinan yang baik.

Keberhasilan dalam

kedisiplinan pimpinan akan menentukan pencapaian kinerja pegawai, khususnya disiplin dalam bersikap terhadap instansi, pekerjaan dan pegawai yang bekerja dalam mengembangkan kinerja organisasi. Adapun indikator kedisiplinan pimpinan pada penelitian ini dibatasi pada:

\section{Disiplin Waktu (X1)}

Pimpinan yang disiplin waktu berarti menunjukkan ketaatan terhadap jam kerja yang telah ditentukan. Adapun kriteria untuk melihat disiplin waktu Pimpinan di Kantor Kelurahan Lompo Riaja.

Hasil penelitian menunjukkan bahwa rata-rata masuk dari jam 08.30, hal tersebut berarti bahwa ketepatan waktu masuk kantor pimpinan di Kantor Kelurahan Lompo Riaja Kabupaten Barru masih merupakan kategori kurang disiplin dengan persentase sebanyak 37,5 persen responden yang memilih kategori tersebut.

\section{Disiplin Peraturan (X2)}

Adapun kriteria untuk melihat disiplin peraturan pimpinan di Kantor Kelurahan Lompo Riaja.

Hasil penelitian menunjukkan sebanyak 43,75 persen responden yang memilih jawaban dengan kategori sering ikut berarti bahwa pimpinan di Kantor Kelurahan Lompo Riaja sering mengikuti upacara.

3. Disiplin Tanggung Jawab (X3)

Adapun kriteria untuk melihat disiplin tanggungjawab pimpinan di Kantor Kelurahan Lompo Riaja.

Hasil penelitian menunjukkan sebanyak 68,75 persen responden yang memilih kategori selalu mengutamakan urusan dinas. Hal tersebut berarti bahwa pimpinan di Kantor Kelurahan Lompo Riaja Kabupaten Barru ketika saat bersamaan menghadapi urusan dinas dan urusan pribadi selalu mengutamakan urusan dinas.

4. Akumulasi Frekuensi Kedisiplinan Pimpinan (X)

Kedisiplinan pimpinan dikatakan baik apabila memenuhi beberapa kriteria, anatara lain yaitu disiplin waktu, disiplin peraturan, dan disiplin tanggung jawab. Secara keseluruhan tanggapan mengenai kedisiplinan pimpinan pada Kantor Kelurahan Lompo Riaja.

Hasil penelitian menunjukkan bahwa frekuensi kedisiplinan pimpinan menunjukkan bahwa kedisiplinan pimpinan pada kantor Kelurahan Lompo Riaja Kabupaten Barru masih berada pada kategori kurang disiplin dengan perolehan persentase sebanyak 56,25 persen. 


\section{B. Kinerja Pegawai (Y)}

Sebagaimana yang diketahui bahwa kinerja aparat pemerintah bertujuan untuk memberikan pelayanan dan memberikan kepuasan kepada publik. Untuk mengetahui kinerja Pegawai Kelurahan Lompo Riaja akan diuraikan sesuai dengan indikator yang dijadikan tolok ukur kinerja sebagai berikut :

\section{Kualitas Pekerjaan (Y1)}

Adapun kriteria untuk melihat kualitas pekerjaan pegawai di Kantor Kelurahan Lompo Riaja.

Hasil penelitian menunjukkan sebanyak 50 persen responden yang memilih kategori jawaban sesuai. Berdasarkan hasil tersebut berarti bahwa pekerjaan yang diselesaikan oleh pegawai Kelurahan Lompo Riaja sesuai dengan standar pelayanan yang ada.

\section{Kuantitas Pekerjaan (Y2)}

Adapun kriteria untuk melihat kuantitas pekerjaan pegawai di Kantor Kelurahan Lompo Riaja Kabupaten Barru.

Hasil penelitian menunjukkan sebanyak 75 persen responden yang memilih kategori jarang. Hal tersebut berarti bahwa pegawai di Kantor Kelurahan Lompo Riaja Kabupaten Barru jarang menyelesaikan pekerjaan secara tepat waktu.

\section{Kerjasama (Y4)}

Adapun kriteria untuk melihat kerjasama pegawai di Kantor Kelurahan Lompo Riaja Kabupaten Barru.

Hasil diatas menunjukkan sebanyak 56,25 persen responden yang memilih kategori jawaban sangat setuju. Hal tersebut berarti bahwa saran dan kririk dari rekan kerja dapat membuat pegawai di Kantor Kelurahan lompo Riaja Kabupaten Barru bekerja lebih baik.

\section{SIMPULAN}

Setelah diadakan pengolahan data berupa analisis frekuensi mengenai kedisiplinan pimpinan dan kinerja pegawai serta pengujian regresi linear sederhana mengenai pengaruh kedisiplinan pimpinan terhadap kinerja pegawai, maka kesimpulan yang dapat dikemukakan adalah sebagai berikut:

1. Hasil penelitian menunjukkan bahwa kedisiplinan pimpinan pada kantor Kelurahan Lompo Riaja Kabupaten Barru masih berada pada kategori kurang disiplin, hal ini bisa dilihat dari nilai akumulasi kedisiplinan pimpinan dengan persentase sebesar 56,25 persen.

2. Hasil penelitian menunjukkan bahwa kinerja pegawai di kantor Kelurahan Lompo Riaja Kabupaten Barru masih berada pada kategori kurang baik, hal ini bisa dilihat dari nilai akumulasi kinerja pegawai dengan persentase sebesar 37,5 persen.

3. Hasil uji regresi yang telah dilakukan secara parsial menunjukkan bahwa pengaruh kedisiplinan pimpinan sebagai variabel independen terhadap kinerja pegawai sebagai variabel dependen memiliki pengaruh yang lemah dan ada beberapa koefisien korelasi yang bernilai negatif, artinya tidak memiliki kontribusi terhadap kinerja pegawai.

4. Hasil uji regresi yang telah dilakukan secara simultan menunjukkan bahwa kedisiplinan 
pimpinan berpengaruh terhadap kinerja pegawai, ini dapat dilihat pada nilai pearson correlation sebesar 0,641 artinya pengaruh kedisiplinan pimpinan terhadap kinerja pegawai cukup kuat.

\section{SARAN}

Mengacu pada hasil pengolahan data pembahasan, maka dapat disarankan sebagai berikut:

1. Hendaknya kedisiplinan pimpinan di Kantor Kelurahan Lompo Riaja Kabupaten Barru agar lebih ditingkatkan karena kedisiplinan pimpinan mempunyai pengaruh yang cukup kuat terhadap kinerja pegawai supaya pegawai pada kantor tersebut mempunyai dorongan dan semangat kerja dalam melaksanakan tugas dan pekerjaannya sehingga menghasilkan kinerja yang baik.

2. Hendaknya pimpinan di Kantor Kelurahan Lompo Riaja Kabupaten Barru perlu bersikap lebih proaktif dan tegas terhadap para pegawai, beliau dapat lebih mengenal dan memahami kondisi dari para pegawai untuk lebih meningkatkan kinerjanya untuk dapat mencapai tujuan yang diinginkan.

3. Peningkatan kinerja para pegawai Kelurahan Lompo Riaja masih harus terus ditingkatkan agar dalam memberikan pelayanan kepada masyarakat dapat dilakukan secara maksimal dan dapat mengerjakan suatu tugasnya dengan waktu yang relatif cepat, serta menghasilkan kualitas layanan yang memuaskan.

4. Dengan segala keterbatasan dalam penelitian ini, penulis berharap agar dilakukan penelitian lebih lanjut terkait dengan variabelvariabel yang telah diteliti sebelumnya.

\section{DAFTAR PUSTAKA}

Amins, Achmad. 2012. Manajemen Kinerja. Yogyakarta: Laksbang Pressindo.

Fahmi, Irham. 2011. Manajement Kinerja (Teori dan Aplikasi). Bandung: Alfabeta.

Handoko, T. Hani. 2010. Manjemen Personalia dan Sumber daya Manusia. Yogyakarta: BPFE.

Hartini, Sri,dkk. 2010. Hukum Kepegawaian Di Indonesia. Jakarta: Sinar Grafika.

Hasibuan, Melayu S.P. 2009. Manajemen Sumber Daya manusia. Jakarta: PT. Bumi Aksara.

Mangkunegara, A.A. Anwar Prabu. 2012. Evaluasi Kinerja SDM. Bandung: PT. Refika Aditama.

Moekijat. 2009. Administrasi Kepegawaian Negara Indonesia. Bandung: CV. Mandar Maju.

Nawawi, 2006. Evaluasi dan Manajemen Kinerja Dilingkungan Perusahaan dan Industri. Yogyakarta: Gadjah Mada University Press.

Sedarmayanti. 2009. Sumber Daya Manusia dan Produktivitas Kerja. Bandung: Mandar Maju. Siagian, Sondang P. 2010. Manajemen Sumber Daya Manusia. Jakarta: Bumi Aksara.

Sugiyono. 2012. Metode Penelitian Kombinasi. Bandung: Alfabeta. 
Surjadi, 2009. Pengembangan

Kinerja Pelayanan Publik.

Bandung: Refika Aditama.

Sutrisno, Edy. 2011. Budaya

Organisasi. Jakarta: Kencana

Prenada Media Group.

Thoha, Miftah. 2008. Manajemen

Kepegawaian Sipil DI

Indonesia. Jakarta: Kencana

Prenada Media Group.

Wibowo. 2010. Manajemen Kinerja.

Jakarta: Raja Grafindo Persada.

Peraturan Perundang-undangan:

Peraturan Pemerintah No.53 Tahun 2010 tentang Disiplin Pegawai Negeri Sipil. 